\title{
Using stable isotopes and quantitative community characteristics to determine a local hydrothermal vent food web
}

\author{
Derk C. Bergquist ${ }^{1, *}$, James T. Eckner ${ }^{2}$, Istvan A. Urcuyo ${ }^{3}$, Erik E. Cordes ${ }^{4}$, \\ Stephane Hourdez ${ }^{5}$, Stephen A. Macko ${ }^{6}$, Charles R. Fisher ${ }^{2}$ \\ ${ }^{1}$ Marine Resources Research Institute, South Carolina Department of Natural Resources, 217 Fort Johnson Road, \\ Charleston, South Carolina 29412, USA \\ ${ }^{2}$ Department of Biology, The Pennsylvania State University, 208 Mueller Laboratory, State College, Pennsylvania 16802, USA \\ ${ }^{3}$ Department of Biology, Gettysburg College, 300 N. Washington Street, Gettysburg, Pennsylvania 17325, USA \\ ${ }^{4}$ OEB Department, Harvard University, 3079 BioLabs, 16 Divinity Avenue, Cambridge, Massachusetts 02138, USA \\ ${ }^{5}$ CNRS, UPMC, UMR 7127, Equipe Ecophysiologie: Adaption et Evolution Moleculaires, Station Biologique, \\ 29680 Roscoff, France \\ ${ }^{6}$ Department of Environmental Sciences, University of Virginia, Charlottesville, Virginia 22903, USA
}

\begin{abstract}
To investigate food web structure in diffuse flow vent environments, an entire macrofaunal community associated with a single aggregation of the tubeworm Ridgeia piscesae was collected from a vent field on the Juan de Fuca Ridge in the NE Pacific. All members of the community were identified and enumerated, and the biomass and stable carbon $\left(\delta^{13} \mathrm{C}\right)$ and nitrogen $\left(\delta^{15} \mathrm{~N}\right)$ isotope ratios were determined for almost all taxa. Symbiont-bearing invertebrates (primarily $R$. piscesae) accounted for a vast majority of the biomass of the community, and 3 presumably grazing bacterivorous gastropods dominated the biomass of the consumer fauna. Biomass and abundance of individuals declined from the bacterivore to the scavenger/detritivore to the predator feeding guild. Several species (a folliculinid ciliate, Idas washingtonia, Provanna variabilis) possessed unique stable isotope signatures, suggesting the possibility of symbiotic relationships with autotrophic bacteria. Stable isotope values varied widely between and occasionally within species in the lowest consumer levels suggesting a great diversity of food source ${ }^{13} \mathrm{C}$ and ${ }^{15} \mathrm{~N}$ composition. Based on the distinct isotopic values of 3 bacterivores, 3 potential pools of isotopically-distinct microbial production were identified. The 4 highest-biomass predatory species (all polynoids) possessed $\delta^{13} \mathrm{C}$ and $\delta^{15} \mathrm{~N}$ values consistent with a diet that included the tubeworm $R$. piscesae, a species comprising $83 \%$ of the total biomass in the collection, and the gastropod Depressigyra globulus, a species comprising $10 \%$ of the total biomass in the collection. A potential specialist predator (Clypeosectus curvus) on folliculinid ciliates was also identified. Overall the study suggested a dominant pattern of energy transfer from microbial producers to symbiont-bearing siboglinid tubeworms, various bacterivores (gastropods, polychaetes and pycnogonids), and detritivorous polychaetes to predaceous polynoids.
\end{abstract}

KEY WORDS: Food web $\cdot$ Trophic structure $\cdot$ Community structure $\cdot$ Hydrothermal vent $\cdot$ Juan de Fuca Ridge $\cdot$ Stable isotopes $\cdot$ Diffuse flow $\cdot$ Ridgeia piscesae

Resale or republication not permitted without written consent of the publishe

\section{INTRODUCTION}

Hydrothermal vents often support highly productive communities of free-living chemoautotrophic bacteria, invertebrate-bacteria symbioses, endemic consumers, and occasional background fauna, but the trophic relationships within these communities remain unresolved. At the base of the vent food web, chemoauto- trophic free-living and symbiotic bacteria use the reduced chemicals abundant in vent effluent to fix carbon (Jannasch 1985, Childress \& Fisher 1992). The free-living bacteria occur in 2 broad forms important for vent consumers: (1) on surfaces exposed to vent effluent (Nelson et al. 1989, Gundersen et al. 1992), and (2) in subsurface pools from which they may be placed in suspension by fluid exiting vent orifices 
(Holden et al. 1998, Huber et al. 2003). Chemoautotrophic bacteria also form symbiotic relationships with a wide range of vent taxa, most commonly with certain polychaetes, mollusks or crustaceans (Childress \& Fisher 1992). Endemic consumers typically include other polychaetes, gastropods and crustaceans, and all of those so far studied show evidence of consuming and assimilating vent production (Van Dover \& Fry 1989, 1994, Fisher et al. 1994, Vereshchaka et al. 2000, Colaço et al. 2002). Vent production also can be transferred into the larger deep-sea food web via direct and indirect exploitation by benthic background fauna (Micheli et al. 2002) and exported in the vent plume (Burd \& Thomson 1994, Mullineaux et al. 1995).

Tunnicliffe (1991) proposed a basic food web structure for the vent environment describing the flow of energy and materials from 3 producer pools (symbioses, attached free-living bacteria and subsurface free-living bacteria) to 4 consumer pools (grazers, suspensionfeeders, scavengers/detritivores and predators) (Fig. 1). In particular Tunnicliffe (1991) stressed 4 energetic pathways: (1) energy exported from the vent community to the surrounding deep sea, (2) energy in bacterial material suspended in hydrothermal fluids and consumed by suspension-feeders, (3) energy in particulate material (detritus and attached bacteria) consumed by grazers and scavengers/detritivores, and (4) energy transferred between bacterial symbionts and their invertebrate hosts. This model describes energy flow on the larger scale of a vent field, but vent fields support a variety of habitat types, defined by their level

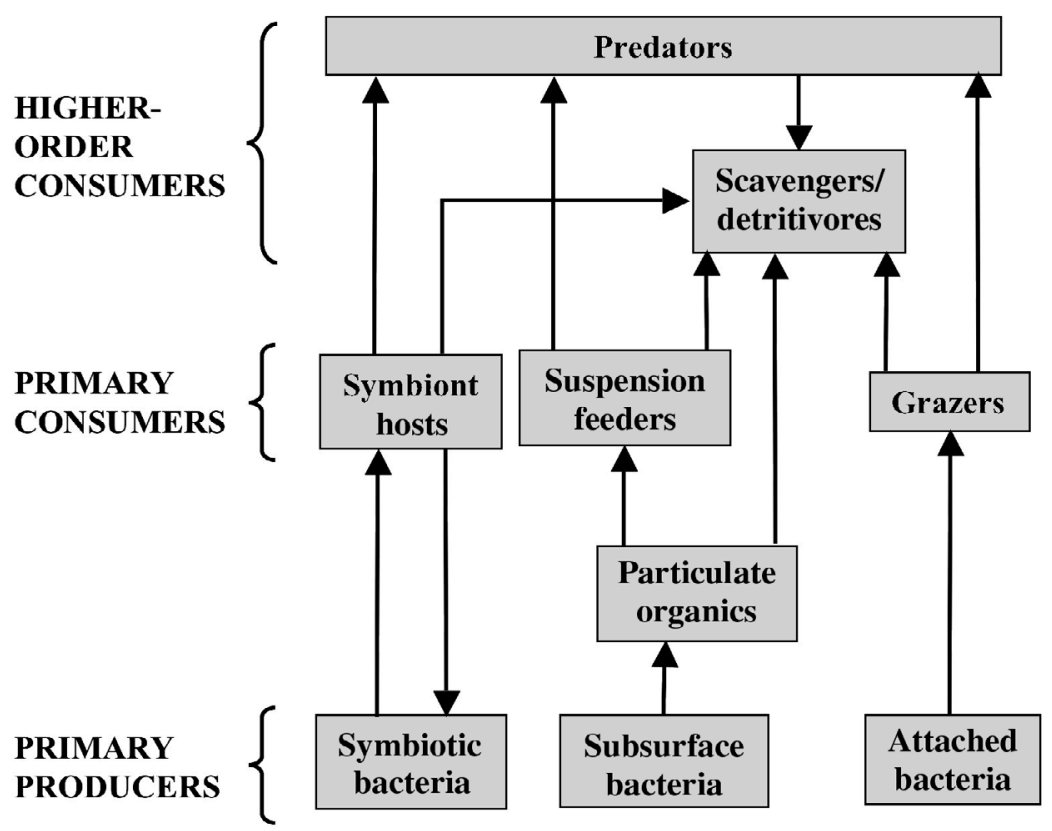

Fig. 1. Hypothetical food web structure in hydrothermal vent community. Arrows indicate direction of energy transfer (consumption). (Modified from Tunnicliffe 1991) of exposure to vent effluent and the dominant species present. Mounting data indicate that producer and consumer communities vary among habitat types within the vent system and that the proportion and physical characteristics of each habitat type varies dramatically in space and time (Hessler et al. 1988, Sarrazin et al. 1997, Shank et al. 1998). In many cases, the same basic suite of consumer species occurs in the different habitat types within a vent field (Sarrazin et al. 1997, Tsurumi \& Tunnicliffe 2001, Govenar et al. 2002), but the relative abundances of these consumer species vary substantially (Govenar et al. 2002). A better understanding of the food webs within these habitat patches is necessary in order to understand not only vent community and ecosystem dynamics but also the transfer of vent production to the surrounding deep-sea.

Because of the inaccessibility of hydrothermal vent environments, studies of trophic structure and energy transfer have primarily utilized stable isotope analyses. These analyses have typically focused upon (1) the carbon and nitrogen sources of specific animals (whether chemoautotrophic or photoautotrophic) (Rau \& Hedges 1979, Rau 1981a,b) or (2) opportunistic collections of macrofaunal producers and consumers, to examine general patterns of use of vent production (Van Dover \& Fry 1989, 1994, Fisher et al. 1994, Vereshchaka et al. 2000). Additional studies of functional morphology and natural history have helped elucidate the trophic roles of specific members of the vent community (for example Desbruyeres et al. 1983, Boetius \& Felbeck 1995, Brescia \& Tunnicliffe 1998, Sancho et al. 2005). As such, the collected fauna are not likely to represent overall community composition, and may provide only a limited perspective regarding the importance of specific taxa in the vent food web. In general, previous studies also considered too few species at a single location (habitat) to allow the construction of a wellconstrained food web for any local community.

On the Endeavor Segment of the Juan de Fuca Ridge (NE Pacific), dense faunal communities assemble on hightemperature chimneys and in lowertemperature diffuse flow fields and reach the highest diversities where the tubeworm Ridgeia piscesae (Polychaeta: Siboglinidae) provides habitat structure (Sarrazin et al. 1997, Sarrazin \& Juniper 1999, Tsurumi \& Tunnicliffe 2001). The chimney environment hosts a variety of different types of communities that can change rapidly from one 
type to another and that tend to be dominated by a rather small number of deposit feeding and grazing species (9 to 16) (Sarrazin et al. 1997, Sarrazin \& Juniper 1999, Govenar et al. 2002). By comparison, relatively little is known of the communities associated with nearby diffuse flow fields, where temperatures and concentrations of reduced chemicals tend to be lower than those in chimney environments (Urcuyo et al. 2003). On the Cleft Segment of the Juan de Fuca Ridge, Tsurumi \& Tunnicliffe (2001) found 28 macrofaunal species in 18 collections that included collections from basaltic communities. Tsurumi \& Tunnicliffe (2003) found 37 macrofaunal taxa amongst 51 collections from 4 different segments of the Juan de Fuca Ridge. In the latter study, the largest numbers of species were found in dense clusters of tubeworms with morphological characteristics typical of tubeworms found in diffuse flow fields of the Endeavor Segment. With the exception of collections by Govenar et al. (2002), however, all collections were made by grabbing clumps of animals with the manipulator of the submersible (without a means of enclosing the collections) or with the ROPOS 'pac-man' sampler for relatively small collections.

In this study, we combine information on the abundance, biomass and carbon and nitrogen stable isotope signatures of various macrofaunal taxa with what is known about their feeding biology in order to construct a local hydrothermal vent food web. Using a comprehensive collection technique, we collected an entire diffuse flow macrofauna community associated with a single Ridgeia piscesae aggregation on the Endeavor Segment of the Juan de Fuca Ridge. The thorough nature of this collection and the very close proximity of all members of the community at the time of collection allow us to suggest trophic links within the community. This diffuse flow habitat supported a strikingly diverse community utilizing variety of food sources within a complex local food web.

\section{MATERIALS AND METHODS}

Collection and preservation. In September 1997, an intact aggregation of Ridgeia piscesae was collected from the Easter Island site on the Main Endeavour segment of the Juan de Fuca Ridge $\left(47^{\circ} 57^{\prime} \mathrm{N}, 129^{\circ} 06^{\prime} \mathrm{W}\right)$ using the DSV, Alvin, (Dive 3138) and a custom-built collection device (Bushmaster Jr). Bushmaster Jr is a hydraulically actuated net, $67 \mathrm{~cm}$ in height and $70 \mathrm{~cm}$ in diameter capable of enclosing and collecting entire aggregations without the loss of associated fauna (Bergquist et al. 2003, Urcuyo et al. 2003); the net used in this collection was of $4 \mathrm{~mm}$ nylon mesh. The $R$. piscesae aggregation collected here was situated over a hydrothermal vent orifice ( $21 \mathrm{~cm}$ diameter) in a diffuse flow environment. This is the same aggregation studied by Urcuyo et al. (2003), who reported data on the chemical and thermal environment within the aggregation over a period of 3 yr prior to collection and data on the tubeworm population including size frequency, sex ratios, mortality rates, incidence of plume predation and growth rates. Although the Bushmaster Jr was lined with a $4 \mathrm{~mm}$ mesh, the aggregation was packed very tightly within the device resulting in the retention of much fauna smaller than $4 \mathrm{~mm}$.

Once aboard the ship, the Bushmaster Jr device was opened over a tarp to prevent loss of fauna, and the aggregation was moved to a cold room where additional macrofauna were removed by hand. Representative individuals of the 15 most readily apparent macrofaunal species were subsampled and frozen $\left(-72^{\circ} \mathrm{C}\right)$ for stable isotope analysis. All remaining macrofauna were preserved in $7 \%$ seawater-buffered formalin. The entire aggregation and any fauna remaining within it were preserved in $7 \%$ seawaterbuffered formalin and shipped to the laboratory, where the aggregation was transferred to a clear plexiglass storage tank containing $70 \%$ ethanol. The aggregation was then thoroughly disassembled, the tubeworm tubes visually inspected for attached macrofauna, and the remaining associated fauna removed, sorted, counted and identified to the lowest possible taxonomic level. The different morphospecies of nematodes and ostracods were not separated. Samples of organisms were sent to specialists for identification and/or description. When possible, each species was assigned a feeding guild (symbiont host, bacterivore, scavenger/detritivore or predator) based upon known feeding biology from the literature. The bacterivore feeding guild included grazers, selective deposit feeders and suspension feeders that appear to specialize in the consumption of free-living bacteria in the vent environment; this assignment simplified the methodology and interpretation in a system where the diets and feeding strategies of many species still require detailed investigation. In the case of less-studied taxa, the known feeding characteristics of closely related species (typically within the same family) were assigned; this was usually only necessary for the very rare species that represented only a small fraction of the individuals and/or biomass in the community. Preserved individuals representing 26 species were taken for additional stable isotope analyses. Feeding guild assignments were modified when stable isotope analyses provided sufficient evidence to do so.

The total wet weight (WW) of each species was determined by patting all individuals dry on a paper towel and weighing (in cases where some individuals had been frozen at sea, those samples were also 
weighed and included). To determine the dry weight of each species, one of 2 methods was employed. For 31 of the more abundant species, a WW to ash-free dry weight (AFDW) conversion factor was determined empirically on a subsample of those individuals collected. For these, between 3 and 6 individuals of each species were wet-weighed, placed in an oven $\left(60^{\circ} \mathrm{C}\right)$ until dry, and then combusted in a muffle furnace $\left(500^{\circ} \mathrm{C}\right)$ to calculate the AFDW. WW:AFDW conversion factors were calculated for each individual and the average was used to generate a conversion factor for each species. For the 12 species that were too small or too few in number to generate a conversion factor, the conversion factor of the closest taxonomic relative in our collection or conversion factors in Ricciardi \& Bourget (1998) were used to calculate contribution to biomass. Because of their small sizes and low abundances, weights were not determined for the bivalve Idas washingtonia or the copepods Aphotopontius forcipatus, Benthoxynus spiculifer, Misophriopsia longicauda and Uptionyx verenae. Weights were not calculated for the folliculinid, a colonial ciliate, because of the difficulty of separating all these from the detritus in the collection.

Sampling and determination of stable isotopes of tissues. Tissue samples for analysis of stable carbon and nitrogen isotope values were collected from 35 species. Samples of 15 taxa were prepared from fresh specimens and frozen at sea. Samples of 26 taxa were prepared from formalin-preserved specimens including samples from 6 taxa also sampled at sea and frozen. Individual Student's $t$-tests were used to compare the stable isotope values between fresh and preserved samples of the 6 taxa for which both kinds of samples were collected. Whenever size of the animals permitted, isolated muscle tissue was removed from the specimen and used for the stable isotope analyses. In the case of smaller taxa, whole intact individuals were analyzed. For gastropods, the shell was removed and only soft tissue was analyzed. In the case of very small species such as ciliates, acari and nematodes, pooled samples of numerous individuals were analyzed. Ciliate samples for stable isotope analyses were carefully separated from detritus.

Stable isotope measurements were made on 0.6 to $1.0 \mathrm{mg}$ of homogenized material obtained after drying samples at $60^{\circ} \mathrm{C}$ for $3 \mathrm{~d}$. A Carlo Erba elemental analyzer coupled to a GV Optima isotope-ratio mass spectrometer (EA/IRMS) was used for all isotopic analyses (Fry et al. 1992). All samples were acidified prior to analysis. Values are expressed in $\delta$ (delta) notation using PDB as the carbon and atmospheric $\mathrm{N}_{2}$ as the nitrogen standards. Although trophic shifts of $+1 \%$ for $\delta^{13} \mathrm{C}$ (Rau et al. 1983) and $+3.5 \%$ for $\delta^{15} \mathrm{~N}$ (Minegawa $\&$ Wada 1984) are normally assumed, we follow the recommendations of the recent meta-analysis by McCutchan et al. (2003), because these were derived from a much larger data set. McCutchan et al. (2003) suggest a consumer shift in $\delta^{13} \mathrm{C}$ of $+0.3 \%$ for whole animal samples and $+1.3 \%$ for muscle tissue samples. Because McCutchan et al.'s (2003) study referred primarily to terrestrial insects possessing a chitin exoskeleton, we applied these standards only to the crustaceans in our collection, and applied a shift of $1.0 \%$ to all other taxa. For $\delta^{15} \mathrm{~N}$, we assumed a shift of $+1.4 \%$ for all invertebrate diets and a shift of $+3.3 \%$ for microbial diets. It is important to note that the values of McCutchan et al. (2003) are quite similar to the historically assumed shifts with the exception of species that consume invertebrates.

\section{RESULTS}

Over $95 \%$ of the Ridgeia piscesae collected were inside the net when it was recovered; the remaining $<5 \%$ were lying prone on the substrate and were not encircled by the Bushmaster Jr. During the collection, the pilot noted fauna falling from the $R$. piscesae not encircled by the net, but otherwise very little material was lost during ascent and recovery of the submersible (pers. obs. I.A.U.). Due to the mesh size used for this collection, the collection of fauna smaller than $4 \mathrm{~mm}$ cannot be considered quantitative. However, many individuals and species smaller than $4 \mathrm{~mm}$ were recovered, since the net was tightly packed with tubeworm tubes that effectively formed a tight mesh inside the collection net. It is also possible that some contamination of the collection by small pelagic species occurred during passage of the submarine through the water column to the surface; 4 unidentified copepod species smaller than $4 \mathrm{~mm}$ and present in very small numbers $(<5$ individuals) that were found in the collection may represent such contamination and were not analyzed further.

\section{Community characteristics}

A total of at least 49 distinct vent species, representing 7 phyla, were found in this tubeworm aggregation (Table 1). The numerically most abundant species were the gastropods Depressigyra globulus (94 594 individuals) and Lepetodrilus fucensis (33 894 individuals), the ampharetid polychaete Amphisamytha galapagensis (7315 individuals), the gastropod Provanna variabilis (5216 individuals) and the tubeworm Ridgeia piscesae (4329 individuals). R. piscesae made up the vast majority of the overall biomass in the collection $(82.88 \%)$ followed by the gastropods D. globulus $(10.24 \%$ of total biomass), $L$. fucensis (4.19\% of total biomass) and $P$. variabilis (1.15\% of total biomass), and the polychaete Nicomache venticola ( $0.65 \%$ of total biomass); 7 gastro- 
Table 1. Fauna collected with Ridgeia piscesae aggregation on the Endeavor Segment of Juan de Fuca Ridge (pr $=$ species for which only preserved samples were used for stable isotope determination, $\mathrm{m}=$ considered as meiofauna based on data in Tables $2 \& 3$ of Tsurumi \& Tunnicliffe 2003). TG: trophic guild $(\mathrm{H}=$ symbiont bearing host, $\mathrm{B}=$ bacterivore, $\mathrm{S}=$ scavenger/detritivore, $\mathrm{P}=$ predator, $\mathrm{d}=$ surface deposit feeder or grazer, s = suspension feeder); (Fig. ID): identification number used in Figs. 3 \& 4 ; No. ind.: no. of individuals; WW: wet weight; AFDW: ash free dry weight (italicized values are estimates); n: number of individuals sampled for stable isotope analysis (PS = pooled sample of numerous individuals). $\delta^{13} \mathrm{C}$ and $\delta^{15} \mathrm{~N}$ values are means (min., max.)

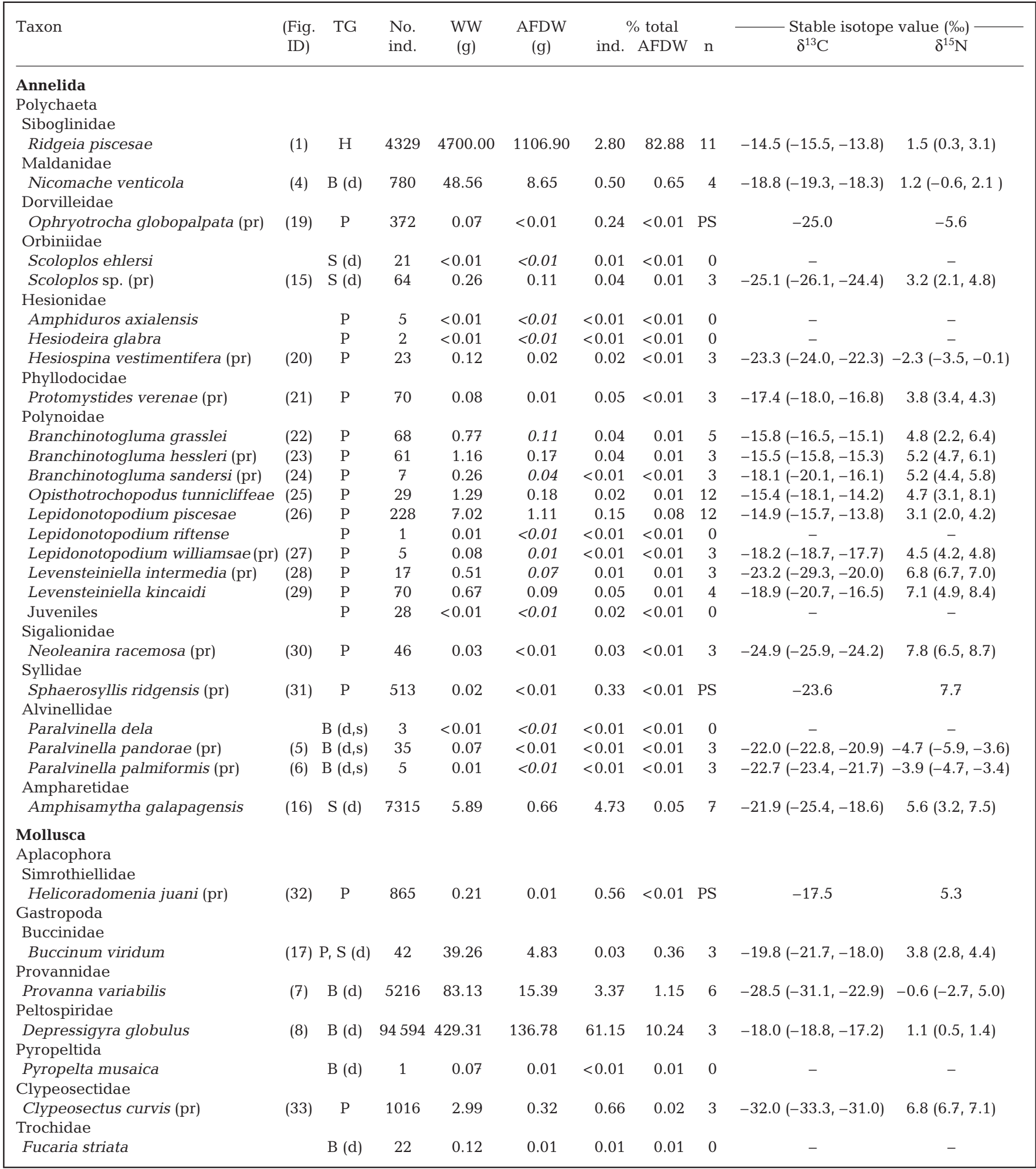


Table 1 (continued)

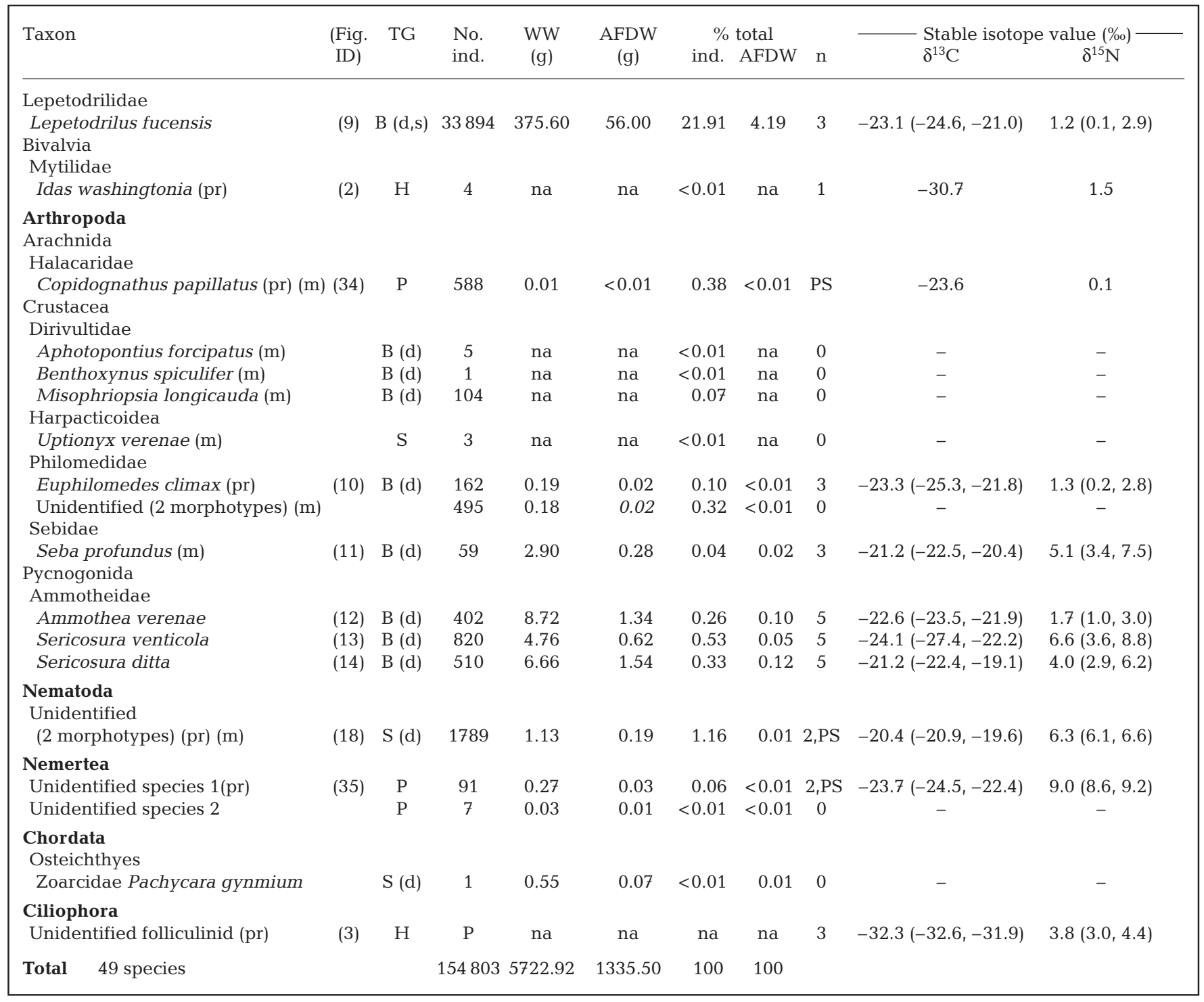

pod species contributed $16 \%$ of the total biomass and accounted for $87 \%$ of the individuals in the collection. Prior to this collection, the polychaetes Branchinotogluma hessleri, Lepidonotopodium riftense, Neoleanira racemosa, Scoloplos ehlersi and Lepidonotopodium williamsae were known only from East Pacific Rise (EPR) sites (Tunnicliffe et al. 1998), bringing the total number of morphospecies shared between the EPR and the NE Pacific Ridges up to 16.

The bacterivore and predator guilds each contained 18 species, while the scavenger/detritovore and symbiont-host guilds comprised substantially fewer species (Fig. 2). Among the heterotrophic fauna, the bacterivore feeding guild was dominant in terms of numerical abundance (92\%) and biomass (97\%). In terms of biomass and/or numerical abundance, the bacterivore feeding guild was dominated by a few grazing gastropods (Depressigyra globulus and Lepetodrilus fucensis), pycnogonids (primarily Ammothea verenae) and deposit-feeding polychaetes (primarily Nicomache venticola). The dominant scavenger/ detritivores were a gastropod (Buccinum viridum), a few deposit-feeding polychaetes (primarily Amphysamytha galapagensis) and nematodes. Polynoid polychaetes accounted for half of the predator species and $97 \%$ of the predator biomass in the community.

\section{Stable isotope analysis}

The mean $\delta^{13} \mathrm{C}$ and $\delta^{15} \mathrm{~N}$ values of frozen and fixed samples were not significantly different in the 4 spe- 

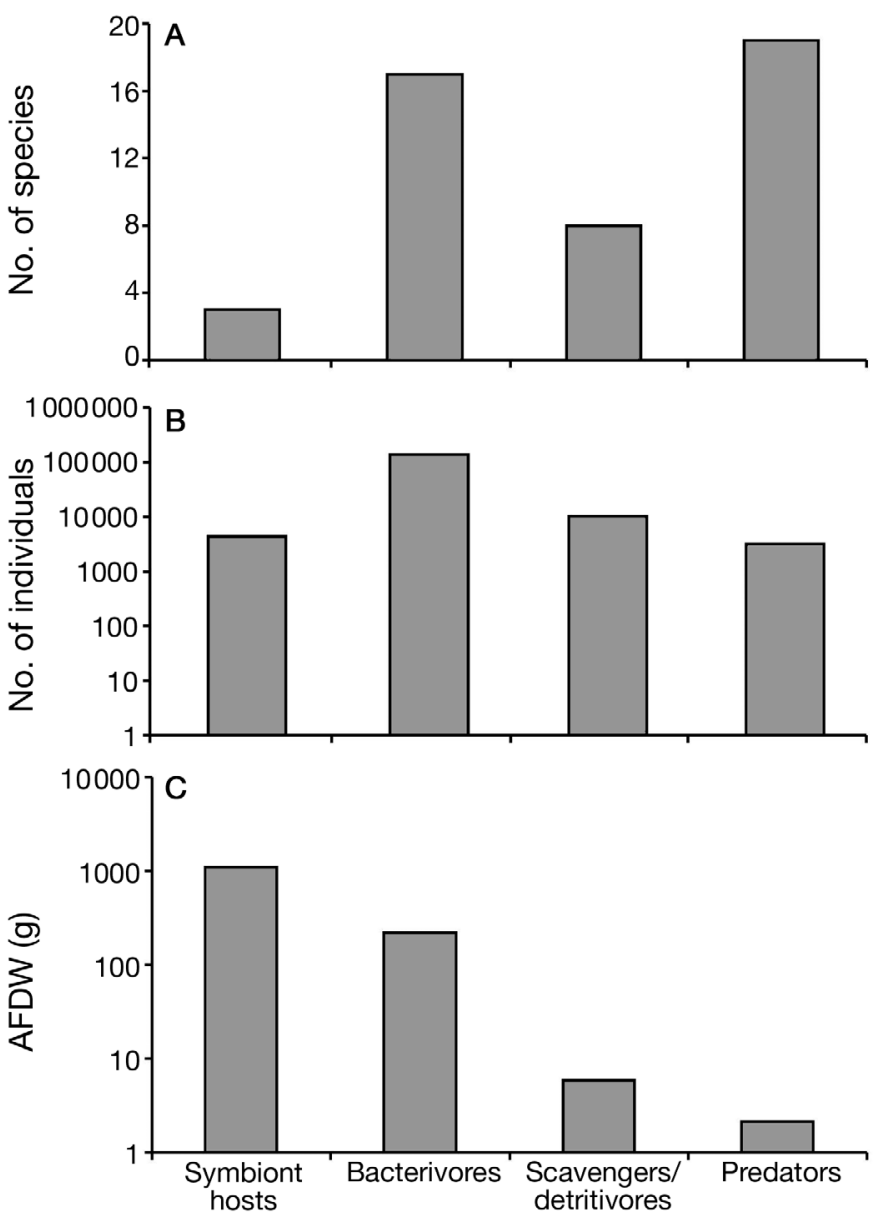

Fig. 2. (A) Number of species, (B) number of individuals and (C) biomass of primary producers, bacterivores, scavengers/ detritivores and predators in the collection
The tissue $\delta^{13} \mathrm{C}$ values of the fauna ranged from -33.3 to $-13.8 \%$ and the $\delta^{15} \mathrm{~N}$ values from -5.9 to $9.2 \%$, falling within the range expected for vent-endemic organisms (Fig. 3A). The majority of species (27 out of 35) possessed $\delta^{13} \mathrm{C}$ values between -27.4 and $-13.8 \%$ and $\delta^{15} \mathrm{~N}$ values between -0.6 and $9.2 \%$ (Fig. 3A,B). Compared to the other putative bacterial symbiontbearing hosts, Ridgeia piscesae (Identity No. [ID] 1 in Fig. 3) had more enriched $\delta^{13} \mathrm{C}$ values (mean = $-14.8 \%$ ) and slightly more enriched $\delta^{15} \mathrm{~N}$ values (mean $=1.5 \%$ ). The folliculinid ciliates [3] and the mussel Idas washingtonia [2] had extremely depleted $\delta^{13} \mathrm{C}$ values (mean $=-33.0$ and $-31.4 \%$, respectively) (Fig. 3A,C). The bacterivores varied widely in $\delta^{13} \mathrm{C}$ value $(-28.5$ to $-18.0 \%$ ); 2 gastropod species, Clypeosectus curvus [33] and Provanna variabilis [7], possessed depleted values similar to the ciliates and mussels (Fig. 3A,C). The scavengers/detritivores had a range of $\delta^{13} \mathrm{C}(-25.8$ to $-19.8 \%$ o) and $\delta^{15} \mathrm{~N}$ (1.2 to $6.3 \%$ o) similar to most of the grazers (Fig. 3A,B). The predators also had a wide range of $\delta^{13} \mathrm{C}$ (-25.6 to $-15.3 \%$ ), but tended to have the most enriched $\delta^{15} \mathrm{~N}$ values, with the exception of the polychaetes Hesiospina vestimentifera [20] and Ophryotrocha globopalpata [19] and the acarid Copidognathus papillatus [34], a species with depleted values, similar to the alvinellids (Fig. 3A,B). Within species, $\delta^{13} \mathrm{C}$ and $\delta^{15} \mathrm{~N}$ values were sometimes quite variable (Fig. 3B,C).

When only those taxa representing the greatest proportion of the biomass in each trophic guild (all symbiont hosts, bacterivores accounting for $>0.5 \%$ of community biomass and the alvinellids, scavengers/ detritivores accounting for $>0.5 \%$ of community bio- cies that could be statistically compared, and were similar in 2 others for which the sample size was too small for statistical comparison (Table 2). Although only polychaetes were used to compare the effect of the formalin preservation method on $\delta^{13} \mathrm{C}$ and $\delta^{15} \mathrm{~N}$ values, other studies have shown similar negligible effects of preservation on other taxa (Rau et al. 1982, Fisher et al. 1994). In fish tissues, Edwards et al. (2002) found a systematic decrease in $\delta^{13} \mathrm{C}$ (ca. $1.1 \%$ ) and an increase in $\delta^{15} \mathrm{~N}$ (ca. $0.5 \%$ ) due to formalin preservation, but similar consistent trends were not apparent here. Therefore, all stable isotope data were pooled within each species regardless of preservation method.
Table 2. Average (SD) $\delta^{13} \mathrm{C}$ and $\delta^{15} \mathrm{~N}$ values of frozen and fixed samples of 6 polychaetes. Also shown are differences (frozen - fixed) and p-values from individual Student's $t$-tests comparing values of frozen and fixed samples

\begin{tabular}{|c|c|c|c|c|c|c|c|}
\hline Species & $\mathrm{n}$ & $\delta^{13} \mathrm{C}$ & diff & $\mathrm{p}$ & $\delta^{15} \mathrm{~N}$ & diff & $\mathrm{p}$ \\
\hline \multicolumn{8}{|c|}{ Ridgeia piscesae } \\
\hline Frozen & 6 & $-14.6(0.7)$ & \multirow[t]{2}{*}{-0.5} & \multirow[t]{2}{*}{0.150} & $1.3(1.1)$ & \multirow[t]{2}{*}{0.5} & \multirow[t]{2}{*}{0.450} \\
\hline Fixed & 5 & $-15.1(0.4)$ & & & $1.8(1.1)$ & & \\
\hline \multicolumn{8}{|c|}{ Brachinotoglumina grasslei } \\
\hline Frozen & 2 & $-15.6(0.7)$ & \multirow{2}{*}{-1.1} & \multirow[t]{2}{*}{0.195} & $4.3(3.0)$ & \multirow[t]{2}{*}{0.9} & \multirow[t]{2}{*}{0.732} \\
\hline Fixed & 3 & $-16.7(0.7)$ & & & $5.2(0.2)$ & & \\
\hline \multicolumn{8}{|c|}{ Opisthotrochopodus tunnicliffeae } \\
\hline Frozen & 6 & $-15.2(0.9)$ & \multirow[t]{2}{*}{-1.1} & \multirow[t]{2}{*}{0.148} & $4.4(1.0)$ & \multirow[t]{2}{*}{0.6} & \multirow[t]{2}{*}{0.438} \\
\hline Fixed & 6 & $-16.3(1.4)$ & & & $5.0(1.8)$ & & \\
\hline \multicolumn{8}{|c|}{ Lepidonotopodium piscesae } \\
\hline Frozen & 6 & $-15.0(0.7)$ & \multirow[t]{2}{*}{-0.5} & \multirow[t]{2}{*}{0.272} & $3.1(0.7)$ & \multirow[t]{2}{*}{0.0} & \multirow[t]{2}{*}{0.920} \\
\hline Fixed & 6 & $-15.5(0.7)$ & & & $3.1(0.8)$ & & \\
\hline \multicolumn{8}{|c|}{ Amphisamytha galapagensis } \\
\hline Frozen & 1 & -23.4 & \multirow[t]{2}{*}{1.0} & \multirow[t]{2}{*}{-} & 3.8 & \multirow[t]{2}{*}{2.0} & \multirow[t]{2}{*}{-} \\
\hline Fixed & 6 & $-22.4(2.9)$ & & & $5.9(1.7)$ & & \\
\hline \multicolumn{8}{|c|}{ Levensteiniella kincaidi } \\
\hline Frozen & 1 & -19.8 & \multirow[t]{2}{*}{0.5} & \multirow[t]{2}{*}{-} & 7.3 & \multirow[t]{2}{*}{-0.3} & \multirow[t]{2}{*}{-} \\
\hline Fixed & 3 & $-19.3(2.1)$ & & & $7.0(1.9)$ & & \\
\hline
\end{tabular}



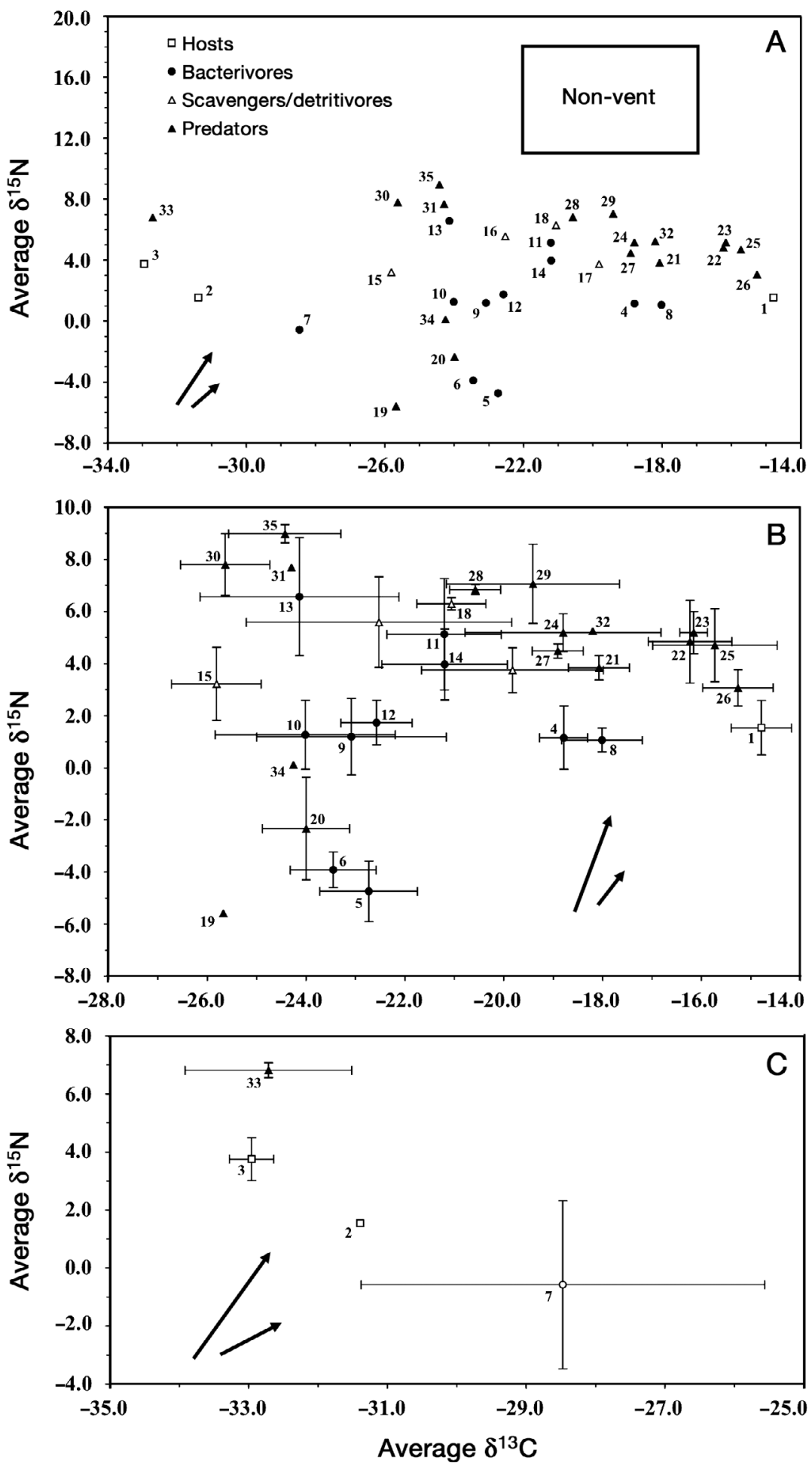

Fig. 3. Mean $\delta^{13} \mathrm{C}$ and $\delta^{15} \mathrm{~N}$ values of each species by feeding guild, showing relative relationships amongst $(\mathrm{A})$ all species and $(\mathrm{B}, \mathrm{C})$ species separated into 2 somewhat smaller groups to provide additional resolution of variability (error bars $= \pm 1 \mathrm{SD}$ ). Non-vent box indicates normal values for background fauna dependent on photosynthetic production. Large and small arrows indicate expected change in $\delta^{13} \mathrm{C}$ and $\delta^{15} \mathrm{~N}$ between trophic levels for microbial and invertebrate diets, respectively $\left(+1.0 \%{ }_{0} \delta^{13} \mathrm{C}_{1}+3.3 \%{ }^{15} \mathrm{~N}\right.$ and $+1.0 \%{ }^{\circ} \delta^{13} \mathrm{C}$ $+1.4 \% \delta^{15} \mathrm{~N}$ respectively). Species identity (ID) nos. as in Table 1 mass, and predators accounting for $>1 \%$ of community biomass) were examined, several potentially strong feeding relationships became apparent (Fig. 4). The $\delta^{13} \mathrm{C}$ and $\delta^{15} \mathrm{~N}$ values of the deposit-feeding alvinellids and several grazer taxa (Depressigyra globulus [8], Lepetodrilus fucensis [9] and Ammothea verenae [12]) suggest 3 large pools of isotopically-distinct, free-living microbial production available to primary consumers (Fig. 4B). Of the 5 highest biomass predatory taxa, 4 (Lepidonotopodium piscesae [26], Branchinotogluma grasslei [22], B. hessleri [23] and Opisthotrochopodus tunnicliffae [25]) had $\delta^{13} \mathrm{C}$ and $\delta^{15} \mathrm{~N}$ values consistent with at least partial consumption of the tubeworm Ridgeia piscesae [1] (Fig. 4C). The polynoids Branchinotogluma sandersi [24], Levensteiniella kincaidi [29] and L. intermedia [28] had $\delta^{13} \mathrm{C}$ and $\delta^{15} \mathrm{~N}$ values that suggested different degrees of diet specialization, but all had diets that may include the pycnogonid Sericosura ditta [14] (Fig. 4D).

\section{DISCUSSION}

The single Ridgeia piscesae aggregation collected here provided habitat for an unexpectedly abundant and rich community of vent fauna (154 803 individuals distributed amongst 39 macrofaunal and 9 meiofaunal taxa not including $R$. piscesae). For perspective, consider that Tsurumi \& Tunnicliffe (2003) reported a total of 350000 individuals of 37 macrofauna and 14 meiofauna taxa from 51 collections of tubeworm communities from 4 segments of the Juan de Fuca Ridge. Of the 81 vent species from the NE Pacific listed in Tunnicliffe et al. (1998), 35 (43\%) were found in the single collection made here. Excluding the nematodes, ciliates and the nemertean, 9 species found in this collection were not listed by Tunnicliffe et al. (1998) as occurring in the NE Pacific. This underscores the utility of more quantitative and comprehensive collection techniques and indicates that biological diversity at many 

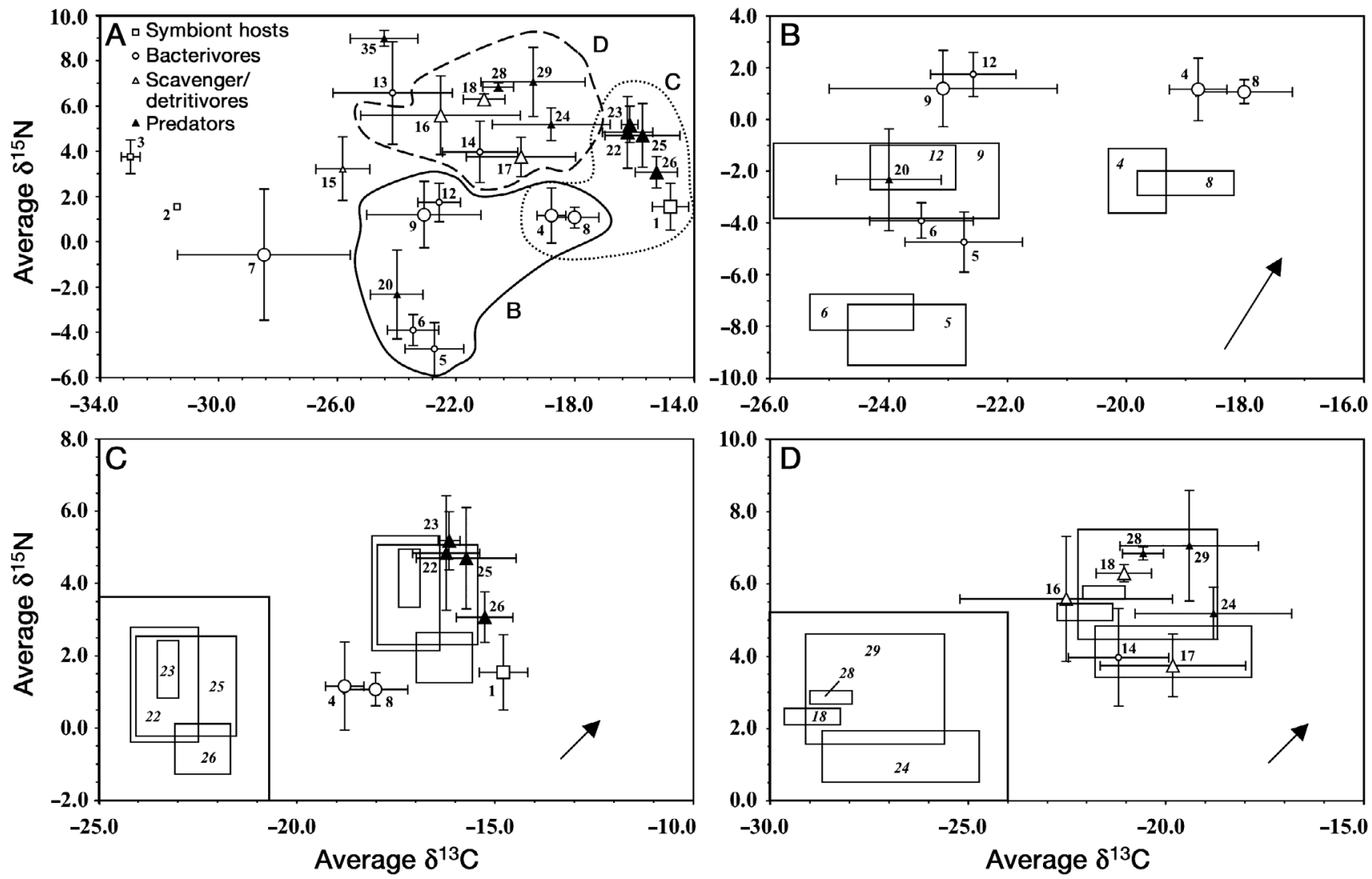

Fig. 4. Mean ( $\pm 1 \mathrm{SD}) \delta^{13} \mathrm{C}$ and $\delta^{15} \mathrm{~N}$ values for the larger portion of food web, involving taxa representing greatest proportions of biomass in each trophic guild. (A) Food web showing 3 focal compartments: (B,C,D); (B) primary consumers with isotopic signatures suggesting different microbial diets. Arrow indicates expected change in $\delta^{13} \mathrm{C}$ and $\delta^{15} \mathrm{~N}$ between trophic levels for a microbial diet $\left(+1.0 \%\right.$ o $\delta^{13} \mathrm{C},+3.3 \%$ o $\left.\delta^{15} \mathrm{~N}\right)$; $(\mathrm{C})$ polynoids with enriched $\delta^{13} \mathrm{C}$ values. Arrow indicates expected change in $\delta^{13} \mathrm{C}$ and $\delta^{15} \mathrm{~N}$ between trophic levels for an invertebrate diet $\left(+1.0 \% \delta^{13} \mathrm{C}_{1}+1.4 \% \delta^{15} \mathrm{~N}\right)$; (D) predators with enriched $\delta^{15} \mathrm{~N}$, intermediate $\delta^{13} \mathrm{C}$ values. Arrow indicates expected change in $\delta^{13} \mathrm{C}$ and $\delta^{15} \mathrm{~N}$ between trophic levels for an invertebrate diet $\left(+1.0 \%\right.$ o $\delta^{13} \mathrm{C},+1.4 \%$ $\delta^{15} \mathrm{~N}$ ). Boxes in (B) to (D) enclose presumed range of stable isotope values for food sources of specific consumers (both based on mean $\pm 1 \mathrm{SD} \delta^{13} \mathrm{C}$ and $\delta^{15} \mathrm{~N}$ values); italicized numbers inside boxes indicate consumer species presumably consuming the food source. Insets in (C) and (D) clarify position of food sources for each consumer. Enlarged symbols represent 3 to 4 highest biomass taxa in each trophic guild. Species identity (ID) nos. as in Table 1

vent sites may be much higher than previously thought.

When the data from the aggregation collected here are compared to those from other collections from the same area, evidence of a general shift from low diversity communities in vigorous and ephemeral sulfide edifice environments to high diversity communities in lower energy, more stable, diffuse flow environments begins to emerge. Sarrazin \& Juniper (1999) described 6 community types on the sulfide edifice S\&M near the site of our collection, and the richest of these communities hosted approximately 16 species (assuming 4 polynoid species and 3 pycnogonid species). Combining the species list of all 6 community types produced a total species richness of 24 for that edifice (with similar assumptions for other taxa). Using a collection device similar to that used in this study, Govenar et al. (2002) identified only 14 species in 5 collections from 3 community types on the sulfide edi- fice Bastille located in the same area. In contrast, Juniper et al. (1992) found 38 species in a single tubeworm aggregation collected from a sedimented, diffuse flow habitat on the northern Juan de Fuca Ridge, a habitat more similar to that sampled here. Of the 51 collections made by Tsurumi \& Tunnicliffe (2003), tubeworm aggregations collected from a basalt substratum consistently hosted a larger number of taxa than those collected from sulfide structure substratum.

The very large numbers of species found in diffuse flow tubeworm aggregations probably reflect the relative heterogeneity and stability of these habitats. While sulfide edifice environments change rapidly (on the scale of months) (Sarrazin et al. 1997), diffuse flow environments appear to remain stable for many years, providing additional opportunities for colonization by species with more restricted dispersal capabilities. Urcuyo et al. (unpubl.) found that tubeworms provid- 


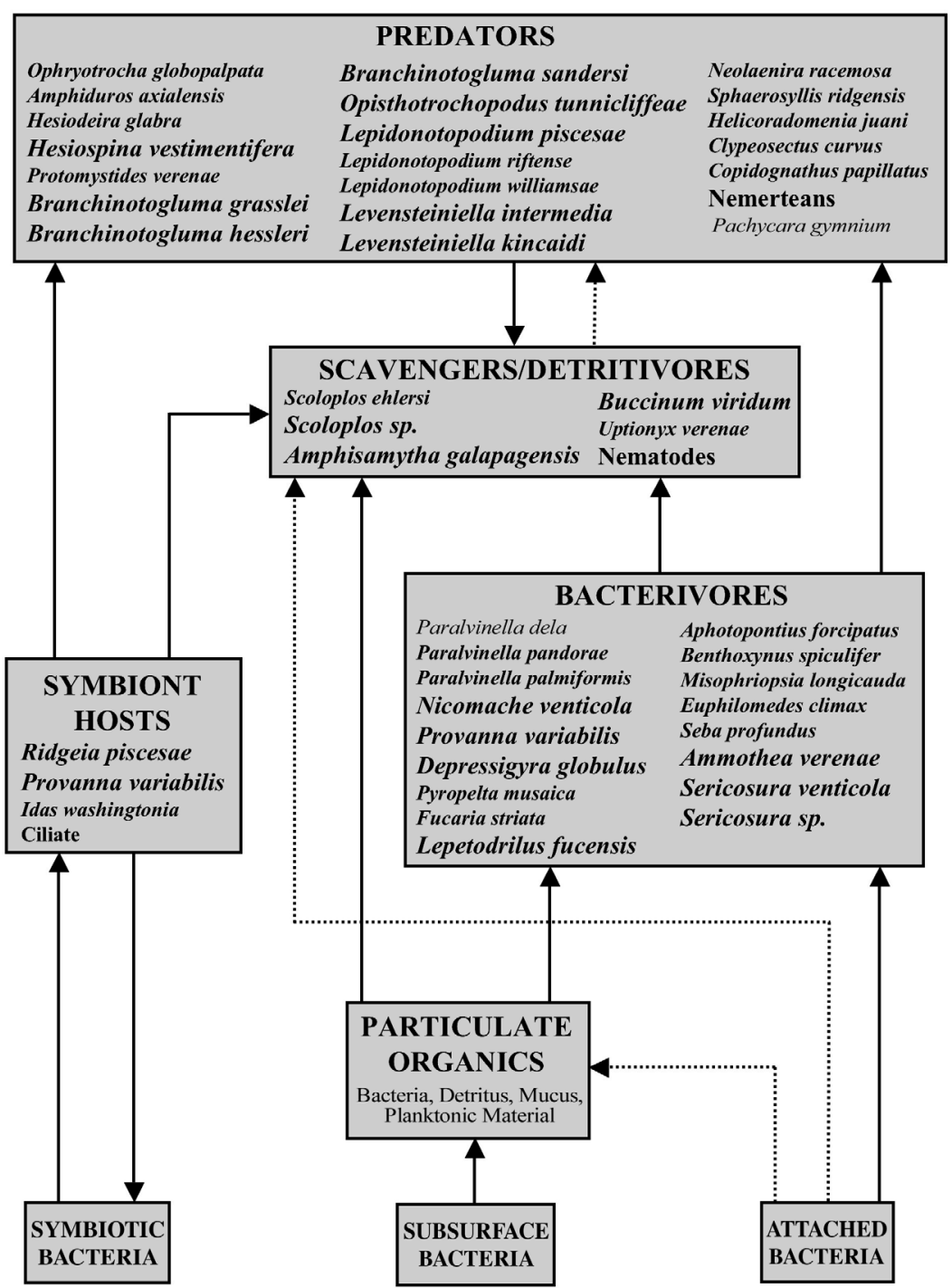

Fig. 5. Hypothesized food web for community associated with aggregation of Ridgeia piscesae in diffuse flow environment. Trophic guilds are based on Tunnicliffe (1991), individual species are assigned to trophic guilds based on published literature, present authors' personal observations, and data obtained in this study. Arrows indicate direction of consumption, with continuous arrows indicating relationships defined in Tunnicliffe (1991) and dotted arrows showing additional likely relationships based on data of current study. Taxa in larger font are those that were dominant (based on biomass) in each trophic guild; taxa in bold are those for which stable isotope values were determined. Note: Provanna variabilis has been moved from 'Grazer' to 'Host' category (see 'Discussion-Bacterivores' for explanation)

ing habitat structure in diffuse flow environments may persist for up to $10 \mathrm{yr}$, suggesting a habitat more stable in time than those associated with sulfide edifices. The aggregation collected here was attached at its base to a vent opening and provided substantial habitat structure along a gradient of vent effluent exposure (Urcuyo et al. 2003). Near its base, this aggregation consisted of a tightly packed network of tubeworm tubes with only small interstitial spaces experiencing average temper- atures of 4 to $10^{\circ} \mathrm{C}$ above ambient. In the more distal portions of the aggregation, the tubes were more widely spaced and experienced temperatures of no more than about $0.5^{\circ} \mathrm{C}$ above ambient over a $1 \mathrm{yr}$ monitoring period (Urcuyo et al. 2003). This indicates that a single aggregation of Ridgeia piscesae can provide substantial habitat heterogeneity involving numerous simultaneous characteristics including size and shape of refugia, exposure to thermal and chemical conditions, and availability of microbial food sources. Based on observational and correlative studies, several authors have proposed that these characteristics contribute substantially to the compo- sition of tubeworm-associated communities (eg. Sarrazin et al. 1997, 1999, Tsurumi \& Tunnicliffe 2003), but experiments designed to test these hypotheses are still lacking.

\section{Local food web}

The basaltic tubeworm community collected here exhibited a complex trophic structure (Fig. 5). With the exception of a very short, ciliate-based food web, the species possessing very depleted $\delta^{13} \mathrm{C}$ values (Fig. $3 \mathrm{~A}_{1} \mathrm{C}_{i}$ a folliculinid ciliate [3], Clypeosectus curvus [33], Idas washingtonia [2] and Provanna variabilis [7]) showed little, if any, evidence of interaction with higher consumer levels (predators and scavengers). The remainder of the fauna, however, consisted of a diverse assemblage of bacterivores, scavengers/ detritivores and predators with complex feeding relationships. Among these fauna, the variability in the average $\delta^{13} \mathrm{C}$ and $\delta^{15} \mathrm{~N}$ values within the bacterivore $\left(\delta^{13} \mathrm{C}\right.$ range $6.13 \%$, $\delta^{15} \mathrm{~N}$ range $\left.11.31 \%\right)$, scavenger/detritivore $\left(\delta^{13} \mathrm{C}\right.$ range $6.0 \%$, $\delta^{15} \mathrm{~N}$ range $3.1 \%$ o) and predator $\left(\delta^{13} \mathrm{C}\right.$ range $10.4 \%$, $\delta^{15} \mathrm{~N}$ range $13.4 \%$ ) feeding guilds indicates that a variety of food resources were available.

Stable isotope analyses suggest the occurrence of both trophic specialists and generalists in this community. Numerous species including Depressigyra globulus, Nicomache venticola, Ammothea verenae and sev- 
eral polynoids possessed narrow ranges of stable isotope values suggestive of specialist feeding strategies. However, the broad range of $\delta^{13} \mathrm{C}$ values within many other species (such as Amphysamytha galapagensis, Buccinum viridum, Branchinotogluma sandersi, Sericosura venticola and Euphilomedes climax) suggests that generalist feeding patterns are common as well. Thus, this community includes species with narrow food resource niches as well as trophic generalists likely to partition habitat along physical environment gradients of vent fluid exposure and habitat architecture (for example, size and shape of tube interstices). While numerous studies have suggested that resource partitioning occurs in vent environments (for example Tsurumi \& Tunnicliffe 2003), none have addressed the relative importance of specialist and generalist strategies.

Also interesting is the abundance of deposit feeders relative to suspension-feeding bacterivores and scavengers/detritivores. In this collection, the alvinellids Paralvinella palmiformis and P. pandorae are the most likely suspension feeders, but even these probably deposit feed (Desbruyeres et al. 1985). In general, deposit feeders are abundant in lower-flow environments where particles can settle from suspension, while suspension feeders are abundant in higher-flow environment where particles remain suspended in the water column (Hughes 1975). Although vent orifices can provide local high-flow environments, the orifice at the base of this tubeworm aggregation was almost completely plugged by the anterior ends of the Ridgeia piscesae tubes that filled the opening (Urcuyo et al. 2003). The general lack of suspension feeders argues against suspended subsurface production as an important source of organic carbon in this community. The abundance of deposit feeders, particularly grazing bacterivorous gastropods, indicates that bacteria attached to exterior surfaces above the seafloor (such as tubeworm tube surfaces) are the primary food source. However, subsurface bacterial material entrained in vent flow (Tunnicliffe et al. 1997, Holden et al. 1998) may also contribute by settling on exposed surfaces, where it is then consumed by deposit-feeders.

\section{Symbiont-bearing fauna}

Symbiont-bearing and potentially symbiont-bearing invertebrates fell into 2 categories: those with depleted $\delta^{13} \mathrm{C}$ values (Idas washingtonia and the folliculinid ciliate) and those with enriched $\delta^{13} \mathrm{C}$ values (Ridgeia piscesae). The enriched $\delta^{13} \mathrm{C}$ values of $R$. piscesae (approximately $-15 \%$ ) mirror those found in other studies involving a variety of vent tubeworm species from geographically disparate locations (Rau 1981b,
Fisher et al. 1994, Southward et al. 1994, Van Dover \& Fry 1994). The $\delta^{13} \mathrm{C}$ value for $I$. washingtonia, while only determined for a single individual, was similar to values found for other symbiont-bearing vent bivalves such as Bathymodiolus thermophilus and Calyptogena magnifica (Rau \& Hedges 1979, Van Dover \& Fry 1989, Fisher et al. 1994). Whether the folliculinid ciliate depends on symbionts has not yet been demonstrated. However, symbioses form between ciliates and chemoautotrophic bacteria in other reducing environments (Bauer-Nebelsick et al. 1996, Nussbaumer et al. 2004), and the very depleted values found here for the folliculinid ciliate corroborate unpublished SEM observations of bacteria covering the surface of this ciliate (C.R.F. unpubl. data).

Based on stable isotope analyses, few consumers specialized on the symbiont-bearing fauna. Van Dover \& Fry (1994) found similar trends in a study of communities from the Gorda Ridge and the Juan de Fuca Ridge. Those authors found that stable isotope values of consumers were inconsistent with a diet of symbiont-bearing invertebrates and concluded that symbiotic production plays a lesser role in the vent food web. The implications of this study and that by Van Dover \& Fry (1994) are 2-fold. First, the data strongly suggest that production supporting most of the non-symbiontbearing fauna originates from some source other than symbiont-bearing fauna, most likely free-living chemoautotrophic bacteria. Second, the data raise the question of the fate of the enormous standing crop of organic carbon contained within the symbiotic guild. While local consumption cannot be entirely ruled out, this carbon may be exported from the vent community (Tunnicliffe \& Jensen 1987, Voight 2000) or consumed in some later successional stage by fauna not sampled in either study.

\section{Bacterivores}

The consumer fauna of this community was dominated by the bacterivore feeding guild (Fig. 5). The striking diversity, abundance and biomass of the bacterivores emphasizes the importance of free-living bacterial rather than symbiont-bearing host production in supporting heterotrophic communities in vent habitats with diffuse flow. Despite the large number of bacterivore taxa, this guild was dominated by a few extremely abundant and high biomass species, specifically the gastropods Depressigyra globulus, Lepetodrilus fucensis and Provanna variabilis, the polychaete Nicomache venticola and the pycnogonids Ammothea verenae, Sericosura venticola and $S$. ditta.

In general, the wide range of $\delta^{13} \mathrm{C}$ and $\delta^{15} \mathrm{~N}$ values between bacterivore species is suggestive of nutri- 
tional sources with a broad range of stable isotope values. The variability in bacterivore $\delta^{13} \mathrm{C}$ and $\delta^{15} \mathrm{~N}$ values may be at least partially explained by the substantial microbial diversity common in vent environments (Wery et al. 2002, Huber et al. 2003) and/or variability in stable isotope composition of a dominant microbial taxon in different microhabitats. To date, no studies have specifically addressed the stable isotopic signatures of microbial producers in this vent system, so linking specific bacterivores to specific microbial prey is not possible. However, the distinct isotopic signatures of several abundant bacterivores allow us to infer the presence of numerous pools of free-living microbial production. In particular, the $\delta^{13} \mathrm{C}$ and $\delta^{15} \mathrm{~N}$ values of the 2 most numerically abundant bacterivores (Depressigyra globulus [8] and Lepetodrilus fucensis [9]) and the deposit-feeding alvinellids suggests the presence of at least 3 abundant, isotopically-distinct free-living microbial food sources for this diffuse flow community (Figs. 4B \& 5). The fact that the biomass of $D$. globulus is 2.5 times that of $L$. fucensis also suggests that the source consumed by $D$. globulus is the most productive of the available microbial pools. Considering the very low alvinellid biomass, the microbial source upon which alvinellids depend probably contributes little to this community relative to the other 2 sources.

The $\delta^{15} \mathrm{~N}$ values of the alvinellids were very depleted relative to those of the dominant mobile bacterivores Depressigyra globulus [8] and Lepetodrilus fucensis [9] (the same bacterivores that colonize sulfide edifices) (Fig. 3A,C). Sulfide edifice communities on the Endeavor Segment tend to be numerically dominated by deposit-feeding alvinellids (Sarrazin et al. 1997, Govenar et al. 2002), but their dominance declines with the reduced edifice porosity and fluid flow rates that accompany edifice maturation (Sarrazin \& Juniper 1999, Sarrazin et al. 2002). The cause of this successional shift has been hypothesized to involve competitive exclusion by diverse mobile grazers and/or declining chemical availability and suspended particle loads due to changes in hydrothermal fluid flow (Sarrazin et al. 1997, Sarrazin \& Juniper 1999, Govenar et al. 2002). The very different stable isotope values of the alvinellids and the mobile grazers found here indicate that these taxa do not share a common food source, a finding consistent with physical environmental characteristics rather than exploitative competitive interactions driving the relative abundances of these species. Stable isotope studies involving chimney communities could help elucidate the generality of these feeding relationships in other vent habitats as well.

The difference in the stable isotope values of the dominant grazers Depressigyra globulus and Lepetodrilus fucensis indicates that these species do not con- sume a common food resource. While D. globulus is likely to be a strictly grazing species, L. fucensis may be capable of switching feeding strategies from primarily surface grazing to suspension-feeding or consumption of bacteria growing on its gill surfaces (de Burgh \& Singla 1984). The latter 2 feeding strategies by $L$. fucensis may account for the very different stable isotope values of these 2 abundant gastropods. Interestingly, both these gastropods may face competition from other species. Nicomache venticola, another biomass dominant in the community, possessed stable isotope values very similar to those of $D$. globulus. Species in the genus Nicomache tend to selectively deposit-feed, and the narrow range of stable isotope values found for $N$. venticola supports such specialization in this species as well. The very similar stable isotope values of both D. globulus [8] and $N$. venticola [4] suggests that these species specialize on consuming a common food source that, interestingly, is not heavily consumed and incorporated by other grazers (Figs. 3A,B \& 4A,B). Similarly, the range of stable isotope values expected for the food source of Ammothea verenae [12] lies entirely within the range expected for L. fucensis [9] (Fig. 4B). In general, pycnogonids are fluid feeders that prey upon the poriferans, cnidarians and bryozoans on which they often live. Because species of these phyla do not typically occur at vents, vent pycnogonids have been hypothesized to graze bacteria. Brescia \& Tunnicliffe (1998) reported that $A$. verenae are often positioned in areas of vent flow and are sometimes covered in bacterial growth, with filamentous bacteria extending from their proboscis. The $A$. verenae collected here displayed somewhat depleted $\delta^{15} \mathrm{~N}$ values, indicative of being at a lower consumer level, and a notably narrow range of stable isotope values, suggesting that they may specialize on a specific bacterial food source. Several distinct possibilities exist to explain the very similar stable isotope values of $L$. fucensis and A. verenae: (1) the 2 species consume different food sources with very similar stable isotope values, (2) both species graze a similar free-living food source, (3) both species grow and consume similar bacteria from their exterior body surfaces, (4) A. verenae consumes the bacteria growing on $L$. fucensis. As $L$. fucensis and $A$. verenae tend to co-occur in many habitats, they may compete widely.

There were 2 other presumed bacterivores (Provanna variabilis [7] and Sericosura venticola [13]) that displayed notably wide ranges of within-species stable isotope values, suggesting they have multiple food sources or a food source with a wide range of stable isotope values (Fig. 3). Of these 2 species, the gastropod $P$. variabilis possesses the most depleted and highly variable stable isotope values, suggesting a food source or physiology strikingly different from that of the other 
grazers. $P$. variabilis may consume a suite of bacteria very different from that consumed by other grazing bacterivores, or it may possess chemoautotrophic symbionts. Although the latter have not been demonstrated in $P$. variabilis, symbioses have been demonstrated in other larger species in the family Provannidae (Stein et al. 1988, Windoffer \& Giere 1997). If this species does in fact possess symbionts, its very wide range of isotopic values may reflect a mixotrophic lifestyle in which individual $P$. variabilis rely to varying extents upon symbiotic and free-living microbial production. Until this is resolved, $P$. variabilis has been assigned to both the bacterivore and symbiont-host feeding guilds (Fig. 5). The pycnogonids in the genus Sericosura, particularly $S$. venticola, have more enriched and variable $\delta^{15} \mathrm{~N}$ values than Ammothea verenae, potentially indicative of a higher consumer level that perhaps combines detritivory with bacterivory. The wide range of stable isotope values found for $S$. venticola also supports the possibility of a more generalist detritivore-like feeding pattern in this species. It is important to note, however, that the highly variable stable isotope values could reflect specialist diets involving food sources with similarly variable isotopic values.

\section{Scavengers/detritivores}

The detritivore feeding guild proved a small one in terms of species, but was intermediate in terms of abundance and biomass. Detailed dietary studies have not been performed on any of these species, and thus their specific feeding habits remain unknown. The ampharetid polychaete Amphysamytha galapagensis possessed highly variable stable isotope values consistent with a generalist detritivore feeding strategy. Members of the Ampharetidae are generally deposit feeders that use buccal tentacles to collect detritus from surfaces near their tubes. The orbiniid polychaete Scoloplos sp. probably consumes a range of bacterial material and detritus, but its unusually depleted $\delta^{13} \mathrm{C}$ value suggests the possibility of a unique bacterial food source. The fairly narrow $\delta^{15} \mathrm{~N}$ yet broad $\delta^{13} \mathrm{C}$ values for the buccinid gastropod Buccinum viridum may reflect a mixed predatory diet or a diet that includes bacteria and detritus. Buccinid gastropods are known predators and scavengers in coastal environments, where they may also consume detritus and graze algae; $B$. viridum may employ a similar omnivorous feeding strategy in vent environments.

Nematodes were included in the scavenger/detritivore feeding guild, but they may in fact comprise numerous species with a wide range of feeding strategies. Because the stable isotope values of the nematodes found here were determined from pooled sam- ples of numerous individuals potentially from several different species, the utility of the stable isotope values is limited. Regardless, the great abundance and biomass of the nematodes attest to the potential importance of meiofauna in the vent food web.

\section{Predators}

All but 3 species within the predator guild possessed stable isotope values that were at the enriched end of those determined within this community. The predator $\delta^{15} \mathrm{~N}$ values indicated that the bulk of the predatory species feed primarily upon bacterivores and scavengers/detritivores. The very high standing crop of these lower level consumers represents a rich source of nutrition for any predator capable of exploiting them, but only the polynoid polychaetes seem to be particularly successful at doing so.

No predator appeared to entirely specialize on Ridgeia piscesae, despite this species representing a potentially abundant food source. However, 4 polynoids (Lepidonotopodium piscesae [26], Branchinotogluma grasslei [22], B. hessleri [23] and Opisthotrochopodus tunnicliffae [25]) had $\delta^{13} \mathrm{C}$ and $\delta^{15} \mathrm{~N}$ values consistent with a diet that might include $R$. piscesae [1] (Fig. 4C). Polynoids are often observed crawling along the distal anterior ends of tubeworm tubes, and video observations have shown them taking bites from exposed tubeworm plumes (I.A.U. and C.R.F. pers. obs.). Urcuyo et al. (2003) reported that $95 \%$ of the tubeworms forming this aggregation had suffered from partial or complete loss of their plumes, their primary gas exchange organ and only body structure routinely exposed outside their tubes. Similar predation by fish and polynoids has been observed in camera deployments and has been suggested as a major source of mortality in R. piscesae on the Axial Segment of the Juan de Fuca Ridge (Tunnicliffe et al. 1990). Unlike the $50 \%$ monthly mortality reported by Tunnicliffe et al. (1990), $R$. piscesae mortality was quite low $(4 \%)$ in the aggregation collected here (Urcuyo et al. 2003). Probably, a portion of the diets of the polynoids $L$. piscesae, $B$. grasslei, $B$. hessleri, $O$. tunnicliffae and possibly other predators come from non-lethal cropping of $R$. piscesae plumes. In particular, the $\delta^{13} \mathrm{C}$ and $\delta^{15} \mathrm{~N}$ values for L. piscesae [26] and their relatively low variability (Fig. $4 \mathrm{C}$ ) suggest that this species is the most frequent consumer of and may specialize to some extent upon $R$. piscesae. The 3 other polynoids (B. grasslei, B. hessleri, O. tunnicliffae) had $\delta^{13} \mathrm{C}$ and $\delta^{15} \mathrm{~N}$ values consistent with a mixed diet that might also include D. globulus [8], N. venticola [4] and perhaps other polynoids. Even if the historical trophic shifts in stable isotope values $\left(+1.0 \delta^{13} \mathrm{C}\right.$ 
and $+3.5 \delta^{15} \mathrm{~N}$ ) were assumed, the boxes indicating the presumed diets of these predators in Fig. 4 would shift -2.1 down the $\delta^{15} \mathrm{~N}$ axis, suggesting diets comprised largely of $D$. globulus and $N$. venticola. The very similar $\delta^{13} \mathrm{C}$ and $\delta^{15} \mathrm{~N}$ values of these 3 polynoids also suggest substantial niche overlap in their food sources. Interestingly, these 4 predatory polynoids ( $L$. piscesae, B. grassleri, B. hessleri, and O. tunnicliffae) were among the most high-biomass predator taxa, and had $\delta^{13} \mathrm{C}$ and $\delta^{15} \mathrm{~N}$ values consistent with a mixed diet that included the 2 highest biomass invertebrate food sources in the community, R. piscesae and $D$. globulus.

The 2 closely related polynoids Levensteiniella intermedia [28] and L. kincaidi [29] had overlapping $\delta^{13} \mathrm{C}$ and $\delta^{15} \mathrm{~N}$ values that would suggest a similar diet (Fig. 4D). However, the wide range of $\delta^{13} \mathrm{C}$ and $\delta^{15} \mathrm{~N}$ values for $L$. kincaidi indicates it to be a generalist predator, while the narrow range of $\delta^{13} \mathrm{C}$ and $\delta^{15} \mathrm{~N}$ values for $L$. intermedia suggests that it may specialize upon an individual prey item. Based on stable isotope values, the diet of $L$. intermedia may include Sericosura ditta [14], Seba profundus [11], Amphisamytha galapagensis [16], the nematodes and perhaps other polynoids, and Buccinum viridum [17] (Fig. 3B). Most of the potential prey items for L. intermedia (in particular S. ditta and A. galapagensis), however, possess variable $\delta^{13} \mathrm{C}$ and $\delta^{15} \mathrm{~N}$ values; thus, if $L$. intermedia specializes upon one of these species, it may also occupy a specific microhabitat in which its prey has a narrower range of $\delta^{13} \mathrm{C}$ and $\delta^{15} \mathrm{~N}$ values. The $\delta^{13} \mathrm{C}$ and $\delta^{15} \mathrm{~N}$ values for the polynoid Branchinotogluma sandersi [24] indicate that this species may prey upon S. ditta as well (Fig. 4D).

The presumed predators Hesiospina vestimentifera [20], Ophryothocha globopalpata [19] and the acarid mite Copidognathus papillatus [34] had unusually low $\delta^{15} \mathrm{~N}$ values, indicating that they may be specialists upon taxa with depleted $\delta^{15} \mathrm{~N}$ values such as the alvinellid polychaetes (Fig. 3A,C). Whether these taxa directly consume alvinellid tissues or whether they specialize on an associated food resource such as mucus or ectosymbiotic bacteria is unclear. $H$. vestimentifera probably does not directly consume the alvinellids, as its mouth parts lack hard components and its gut often contains a viscous liquid rather than identifiable food items such as polychaete setae (S.H. pers. obs.). The mite C. papillatus may be a parasite specializing on a specific tissue or body fluid of 1 species in the community; however, mites of the family Halacaridae tend to possess a complex life cycle including larval, nymphal and adult stages (Bartsch 2004). Such a potentially complex life cycle involving an ontogenetic shift in diet might contribute to the unusual stable isotope values for this species. The pre- sumably predaceous polychaete $O$. globopalpata possessed a surprisingly depleted $\delta^{15} \mathrm{~N}$ value, with no discernible food source (Fig. 3). Because only a single analysis was conducted on a pooled sample of intact individuals, the values for this species are suspect.

The less abundant polychaetes Lepidonotopodium williamsae [27] and Protomystides verenae [21] and the aplacophoran Helicoradomenia juani [32] had $\delta^{13} \mathrm{C}$ and $\delta^{15} \mathrm{~N}$ values suggestive of a diet including Nicomache venticola [4] and Depressigyra globulus [8] (Fig. 3C). L. williamsae and $P$. verenae both had narrow ranges of $\delta^{13} \mathrm{C}$ and $\delta^{15} \mathrm{~N}$, consistent with specialization on food sources associated with $N$. venticola and D. globulus. The strong jaws of $L$. williamsae and the presence of whole shells and shell fragments within its gut (S.H. pers. obs.) support a diet that includes D. globulus. Finally, the polychaetes Neoleanira racemosa [30] and Sphaerosyllis ridgensis [31] and the nemertean [35] have $\delta^{13} \mathrm{C}$ and $\delta^{15} \mathrm{~N}$ values that suggest nutritional sources very different from those of the other predators (Fig. 3A). Based only on $\delta^{13} \mathrm{C}$ and $\delta^{15} \mathrm{~N}$ values, the detritivores Scoloplos sp., and perhaps to a lesser extent Amphisamytha galapagensis [16], provide potential food sources (Fig. 3A,B). Interestingly, stable isotope analyses also suggest that several abundant lower level consumers such as Lepetodrilus fucensis [9], Amphisamytha galapagensis [16], Provanna variabilis [7] and Ammothea verenae [12] have few if any significant specialist predators in this environment (Figs. $3 \& 4$ ).

The stable isotope values for Clypeosectus curvus [33] and their relatively low variability suggest that this gastropod specializes on consuming the blue-pigmented folliculinid ciliate [3] (Fig. 3A,C). A diet of ciliates is further supported by observations of blue material in the gut and on the mouthparts of this gastropod. The specificity and distribution of this feeding relationship deserves further attention.

The $\delta^{13} \mathrm{C}$ values of the predators tended to be more depleted than expected if one assumes diets of grazers and scavengers/detritivores and enrichment of $\delta^{13} \mathrm{C}$ values at higher trophic levels. For example, while the $\delta^{15} \mathrm{~N}$ value of Hesiospina vestimentifera suggests a food source associated with the alvinellids (more probably mucus and associated bacteria than alvinellid tissue), its $\delta^{13} \mathrm{C}$ value is more depleted than that of the alvinellids, and does not suggest any other potential carbon source for this species. Similarly, while the $\delta^{15} \mathrm{~N}$ values of Neoleanira racemosa and the nemertean suggests consumption of the pycnogonid Sericosura venticola, the polychaete Scoloplos sp. or an associated food source, their $\delta^{13} \mathrm{C}$ values are again more depleted than would be expected. Similar trends hold amongst practically all predators. It is important to note that the guts of the lower level consumers (the prey items) are 
likely to contain ingested free-living bacteria, and their external body surfaces probably host free-living chemoautotrophic bacteria colonists. For example, alvinellids have been shown to possess a dense and diverse assemblage of external bacteria (Prieur et al, 1990), and dense bacterial growth has been observed on the shells of some gastropods such as Depressigyra globulus (C.R.F. and I.A.U. pers. obs.). As a result, many of the predators are probably omnivorous, consuming both animal tissue and chemoautotrophic bacteria, which may account for their unexpectedly depleted carbon signature.

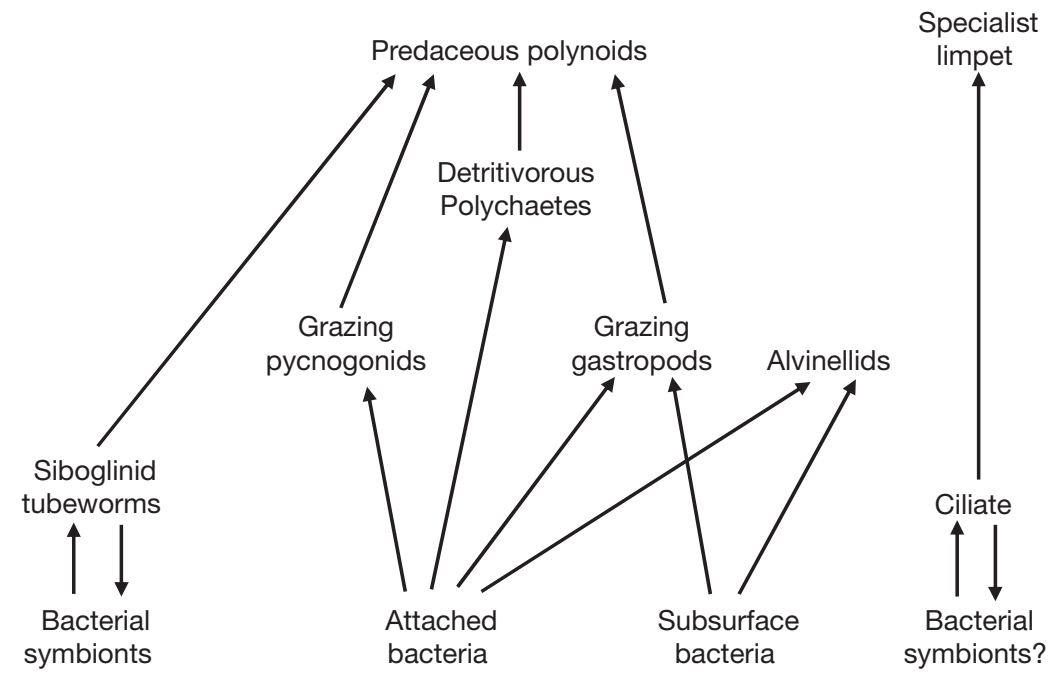

Fig. 6. Dominant food web structure in diffuse flow community examined herein. Arrows indicate direction of consumption

\section{CONCLUSION}

The Ridgeia piscesae-dominated diffuse flow habitat examined here supported a diverse community with a complex trophic structure (Fig. 5). Of the 4 energetic pathways identified by Tunnicliffe (1991) for the vent food web, this study highlights the importance of two of these within the diffuse flow habitat: (1) the consumption of free-living microbial production and (2) the transfer of energy from symbionts to host invertebrates and the ensuing consumption of host tissues within the vent community. At the base of this diffuse flow food web is an abundant and isotopically-varied food source likely to stem from multiple microbial pools, numerous bacterial-invertebrate symbioses, an accumulating detrital pool, and a largely unstudied micro- and meiofaunal community. These support a diverse, abundant and high-biomass community of bacterivores and detritivores that appear to partition resources along numerous environmental gradients and are themselves prey to a species-rich predator guild. The unique and depleted stable isotope values of several species, the folliculinid ciliate, Idas washingtonia and Provanna variabilis, suggest these may be symbiotic with chemoautotrophic bacteria.

The trophic structure of this community appeared to be divided into 2 distinct food webs: (1) a small, largely independent food web consisting primarily of the gastropod Clypeosectus curvus and the folliculinid ciliate, and (2) a large and complex web including most other members of the community (Fig. 6). The $\delta^{13} \mathrm{C}$ and $\delta^{15} \mathrm{~N}$ values of the suspension/deposit feeding alvinellids, the dominant grazing gastropods, putatively grazing pycnogonids, and detritivorous polychaetes and gastropods suggests that the larger food web is based on at least 3 isotopically-distinct, free-living microbial sources of primary production. Additionally, polynoids dominate the predator guild and appear to feed upon symbiont-bearing siboglinid tubeworms, bacterivorous gastropods, polychaetes and pycnogonids, and detritivorous polychaetes and gastropods (Fig. 6). These same basic taxa dominate the grazer, detritivore and predator feeding guilds of many different vent communities in the eastern Pacific (Govenar et al. 2002, 2004; Sarrazin \& Juniper 1999), suggesting that this is a widespread and robust food web structure in these environments.

The sharp contrast in physical environmental characteristics and community structure between sulfide edifice and diffuse flow communities suggests that the relative importance of the various energetic pathways within a food web will vary dramatically in space and time even within a vent field. However, the basic trophic structure (consisting of grazing gastropods, deposit-feeding alvinellids, detritivorous polychaetes and gastropods and predaceous polynoids) remains largely intact across a wide range of vent habitats in the eastern Pacific. While this study constitutes a first step in understanding the complex feeding relationships within the diffuse flow habitat, the relative roles of local cycling versus import/export of energy and nutrients in any single vent habitat remain a mystery.

Acknowledgements. We sincerely thank the captain, crew and pilots of the RV 'Atlantis' and DSRV 'Alvin'. This work was supported by the National Science Foundation (OCE 9633105 to C.R.F.) and the West Coast National Oceanic and Atmospheric Administration National Undersea Research Center. For taxonomic assistance we thank A. Child (pycnogonids), J. Ott (nematodes and ciliates), M. Tsurumi (copepods), A. Humes (copepods) L. S. Kornicker (ostracods), J. 
Norenburg (nemertean) and R. Gustafson (bivalve). The nemerteans were initially examined by P. Gibbs and M. Rice. The detailed community-level information would not have been obtained without the tireless assistance of J. Bubb, J. Dohanich, A. Podey, T. Pundiak, A. Genson, C. Ludwig, A. Mondelblatt and P. Murray. Kim Juniper, Angela Kouris and 3 anonymous reviewers provided suggestions that greatly improved this manuscript.

\section{LITERATURE CITED}

Bartsch I (2004) Geographical and ecological distribution of marine halacarid genera and species (Acari: Halacaridae). Exp Appl Acarol 34:37-58

Bauer-Nebelsick M, Bardele CF, Ott JA (1996) Electron microscopic studies on Zoothamnium niveum (Hemprich \& Ehrenberg, 1831) Ehrenberg, 1838 (Oligohymenophora, Peritrichida), a ciliate with ectosymbiotic, chemoautotrophic bacteria. Eur J Protistol 32:202-215

Bergquist DC, Ward RT, Cordes E, McNelis T and 5 others (2003) Community structure of vestimentiferan-generated habitat islands from upper Louisiana slope cold seeps. J Exp Mar Biol Ecol 289:197-222

Boetius A, Felbeck H (1995) Digestive enzymes in marine invertebrates from hydrothermal vents and other reducing environments. Mar Biol 122:105-113

Brescia LA, Tunnicliffe V (1998) Population biology of two pycnogonid species (Ammotheidae) at hydrothermal vent in the northeast Pacific. Cah Biol Mar 39:233-236

Burd BJ, Thomson RE (1994) Hydrothermal venting at Endeavour Ridge: effect on zooplankton biomass throughout the water column. Deep Sea Res I 41:1407-1423

Childress JJ, Fisher CR (1992) The biology of hydrothermal vent animals: physiology, biochemistry and autotrophic symbioses. Oceanogr Mar Biol Annu Rev 30:337-441

Colaço A, Dehairs F, Desbruyeres (2002) Nutritional relations of deep-sea hydrothermal fields at the Mid-Atlantic Ridge: a stable isotope approach. Deep-Sea Res I 49:395-412

DeBurgh ME, Singla CL (1984) Bacterial colonization and endocytosis on the gill of a new limpet species from a hydrothermal vent. Mar Biol 84:1-6

Desbruyeres D, Gaill F, Laubier L, Fouquet Y (1985) Polychaetous annelids from hydrothermal vent ecosystems: an ecological overyiew. Biol Bull Soc Wash 6:103-116

Desbruyeres D, Chevaldonne P, Alayse AM, Jollivet D and 14 others (1998) Biology and ecology of the 'Pompeii worm' (Alvinella pompejana Desbruyeres and Laubier), a normal dweller of an extreme deep-sea environment: a synthesis of current knowledge and recent developments. Deep Sea Res II 45:383-422

Edwards MS, Turner TF, Sharp ZD (2002) Short- and longterm effects of fixation and preservation on stable isotope values $\left(\delta^{13} \mathrm{C}, \delta^{15} \mathrm{~N}, \delta^{34} \mathrm{~S}\right)$ of fluid-preserved museum specimens. Copeia 2002:1106-1112

Fisher CR, Childress JJ, Macko SA, Brooks JM (1994) Nutritional interactions in Galapagos Rift hydrothermal vent communities: inferences from stable carbon and nitrogen isotope analyses. Mar Ecol Prog Ser 103:45-55

Fry B, Brand W, Mersch FJ, Tholke K, Garritt R (1992) Automated-analysis system for coupled delta-c-13 and delta-n15 measurements. Anal Chem 64:288-291

Govenar BW, Bergquist DC, Urcuyo IA, Eckner JT, Fisher CR (2002) Three Ridgeia piscesae assemblages from a single Juan de Fuca Ridge sulfide edifice: structurally different and functionally similar. Cah Biol Mar 43:247-252
Govenar BW, Freeman M, Bergquist DC, Johnson GA, Fisher CR (2004) Composition of a one-year old Riftia pachyptila community following a clearance experiment: insight to succession patterns at deep-sea hydrothermal vent. Biol Bull 207:177-182

Gundersen JK, Jørgensen BB, Larsen E, Jannasch HW (1992) Mats of giant sulphur bacteria on deep-sea sediments due to fluctuating hydrothermal flow. Nature 360:454-456

Hessler RR, Smithey WM, Boudrias MA, Keller CH, Lutz RA, Childress JJ (1988) Temporal change in megafauna at the Rose Garden hydrothermal vent. Deep-Sea Res I 35: $1681-1710$

Holden JF, Summit M, Baross JA (1998) Thermophilic and hyperthermophilic microorganisms in 3-30 degrees $\mathrm{C}$ hydrothermal fluids following a deep-sea volcanic eruption. FEMS Microbiol Ecol 25:33-41

Huber JA, Butterfield DA, Baross JA (2003) Bacterial diversity in subseafloor habitat following a deep-sea volcanic eruption. FEMS Microbiol Ecol 43:393-409

Hughes RG (1975) The distribution of epizoites on the hydroid Nemertisia antennina. J Mar Biol Assoc UK 55:275-294

Jannasch HW (1985) The chemosynthetic support of life and the microbial diversity at deep-sea hydrothermal vents. Proc R Soc Lond B 225:277-297

Juniper SK, Tunnicliffe V Southward EC (1992) Hydrothermal vents in turbidite sediments on a Northeast Pacific spreading center; organisms and substratum at an ocean drilling site. Can J Zool 70:1792-1809

McCutchan JH Jr, Lewis WM Jr, Kendall C, McGrath CC (2003) Variation in trophic shift for stable isotope ratios of carbon, nitrogen and sulfur. Oikos 102:378-390

Micheli F, Peterson CH, Mullineaux LS, Fisher CR, Mills SW, Sancho G, Johnson GA, Lenihan HS (2002) Species interactions at deep-sea hydrothermal vents: predation structures communities in an extreme environment. Ecol Monogr 72:365-382

Minegawa M, Wada E (1984) Stepwise enrichment of ${ }^{15} \mathrm{~N}$ along food chains: further evidence and the relation between $\delta^{15} \mathrm{~N}$ and animal age. Geochim Cosmochim Acta 48:1135-1140

Mullineax LS, Wiebe PH, Baker ET (1995) Larvae of benthic invertebrates in hydrothermal vent plumes over Juan de Fuca Ridge. Mar Biol 122:585-596

Nelson DC, Wirsen CO, Jannasch HW (1989) Characterization of large autotrophic Beggiatoa spp. abundant at hydrothermal vents of the Guaymas Basin Gulf of California USA. Appl Environ Microbiol 55:2909-2917

Nussbaumer AD, Bright M, Baranyi C, Beisser CJ, Ott JA (2004) Attachment mechanisms in a highly specific association between ectosymbiotic bacteria and marine nematodes. Aquat Microb Ecol 34:239-246

Prieur D, Chamroux S, Durand P, Erauso G, and 5 others (1990) Metabolic diversity in epibiotic microflora associated with the Pompeii worms Alvinella pompejana and $A$. caudata (Polychaeta: Annelida) from deep-sea hydrothermal vents. Mar Biol 106:361-367

Rau GH (1981a) Low ${ }^{15} \mathrm{~N} /{ }^{14} \mathrm{~N}$ in hydrothermal vent animals: ecological implications. Nature 289:484-485

Rau GH (1981b) Hydrothermal vent clam and tubeworm ${ }^{13} \mathrm{C} /{ }^{12} \mathrm{C}$ : further evidence of non-photosynthetic food sources. Science 213:338-340

Rau GH, Hedges JI (1979) Carbon-13 depletion in a hydrothermal vent mussel: suggestion of a chemosynthetic food source. Science 203:648-649

Rau GH, Sweeney RE, Kaplan IR (1982) Plankton ${ }^{13} \mathrm{C}:{ }^{12} \mathrm{C}$ ratio changes with latitude: differences between northern and southern oceans. Deep Sea Res I 29:1035-1039 
Rau GH, Mearns AJ, Young DR, Olsen RJ, Schafer HA, Kaplan IR (1983) Animal ${ }^{13} \mathrm{C} /{ }^{12} \mathrm{C}$ correlates with trophic levels in pelagic food webs. Ecology 64:1314-1318

Ricciardi A, Bourget E (1998) Weight to weight conversion factors for marine benthic invertebrates. Mar Ecol Prog Ser 163:245-251

Sancho G, Fisher CR, Mills S, Micheli F, Johnson GA, Lenihan HS, Peterson CH, Mullineaux LS (2005) Selective predation by the zoarcid fish Thermarces cerberus at hydrothermal vents. Deep Sea Res I 52:837-844

Sarrazin J, Juniper SK (1999) Biological characteristics of a hydrothermal edifice mosaic community. Mar Ecol Prog Ser 185:1-19

Sarrazin J, Robigou V, Juniper SK, Delaney JR (1997) Biological and geological dynamics over four years on a high-temperature sulfide structure at the Juan de Fuca Ridge hydrothermal observatory. Mar Ecol Prog Ser 153: $5-24$

Sarrazin J, Juniper SK, Massoth G, Legendre P (1999) Physical and chemical factors influencing species distributions on hydrothermal sulfide edifices of the Juan de Fuca Ridge, northeast Pacific. Mar Ecol Prog Ser 190:89-112

Sarrazin J, Levesque C, Juniper SK, Tivey MK (2002) Mosaic community dynamics on Juan de Fuca Ridge sulphide edifices: substratum, temperature and implications for trophic structure. Cah Biol Mar 43:275-279

Shank TM, Fornari DJ, Von Damm KL, Lilley MD, Haymon RM, Lutz RA (1998) Temporal and spatial patterns of biological community development at nascent deep-sea hydrothermal vents ( $9^{\circ} 50^{\prime} \mathrm{N}$, East Pacific Rise). Deep-Sea Res I 45:465-515

Southward AJ, Southward EC, Spiro B, Rau GH, Tunnicliffe V (1994) ${ }^{13} \mathrm{C} /{ }^{12} \mathrm{C}$ of organisms from Juan de Fuca Ridge hydrothermal vents: a guide to carbon and food sources. J Mar Biol Assoc UK 74:265-278

Stein JL, Cary SC, Hessler RR, Ohta S, Vette RD, Childress JJ, Felbeck H (1988) Chemoautotrophic symbiosis in a hydrothermal vent gastropod. Biol Bull (Woods hole) 174: 373-378

Tsurumi M, Tunnicliffe V (2001) Characteristics of a hydrothermal vent assemblage on a volcanically active segment of the Juan de Fuca Ridge, northeast Pacific. Can J Fish Aquat Sci 58:530-542

Tsurumi M, Tunnicliffe V (2003) Tubeworm-associated com-

Editorial responsibility: Howard Browman (Associate Editorin-Chief), Storebø, Norway munities at hydrothermal vents on the Juan de Fuca Ridge, northeast Pacific. Deep Sea Res I 50:611-629

Tunnicliffe V (1991) The biology of hydrothermal vents: ecology and evolution. Oceanogr Mar Biol Annu Rev 29: 319-407

Tunnicliffe V, Jensen G (1987) Distribution and behaviour of the spider crab Macroregonia macrochira Sakai (Brachyura) around the hydrothermal vents of the northeast Pacific. Can J Zool 65:2443-2449

Tunnicliffe V, Garrett JF, Johnson HP (1990) Physical and biological factors affecting the behavior and mortality of hydrothermal vent tubeworms (vestimentiferans). Deep Sea Res I 37:103-125

Tunnicliffe V, Embley RW, Holden JF, Butterfield DA, Massoth GJ, Juniper SK (1997) Biological colonization of new hydrothermal vents following an eruption on Juan de Fuca Ridge. Deep-Sea Res I 44:1627-1644

Tunnicliffe V, McArthur AG, McHugh D (1998) A biogeographical perspective of the deep-sea hydrothermal vent fauna. Adv Mar Biol 34:353-442

Urcuyo IA, Massoth GJ, Julian D, Fisher CR (2003) Habitat, growth and physiological ecology of a basaltic community of Ridgeia piscesae from the Juan de Fuca Ridge. Deep Sea Res I 50:763-780

Van Dover CL, Fry B (1989) Stable isotopic composition of hydrothermal vent organisms. Mar Biol 102:257-263

Van Dover CL, Fry B (1994) Microorganisms as food sources at deep-sea hydrothermal vents. Limnol Oceanogr 39: $51-57$

Vereshchaka AL, Vinogradov GM, Lein AY, Dalton S, Dehairs F (2000) Carbon and nitrogen isotopic composition of the fauna from the Broken Spur hydrothermal vent field. Mar Biol 136:11-17

Voight J (2000) A review of predators and predation at deep sea hydrothermal vents. Cah Biol Mar 41:155-166

Wery N, Cambon-Bonavita MA, Lesongeur F, Barbier G (2002) Diversity of anaerobic heterotrophic thermophiles isolated from deep-sea hydrothermal vents of the Mid-Atlantic Ridge. FEMS Microbiol Ecol 41: $105-114$

Windoffer R, Giere O (1997) Symbiosis of the hydrothermal vent gastropod Ifremeria nautilei (Provannidae) with endobacteria - structural analyses and ecological considerations. Biol Bull (Woods Hole) 193:381-392

Submitted: June 24, 2005; Accepted: March 7, 2006

Proofs received from author(s): December 19, 2006 